\title{
The effect of background music played on the multiple intelligence fields in 6 years
}

\section{Elif Erol, Ercan Mertoğlu *}

\author{
Cagev* \\ E-mail: elifkoca5@yahoo.com*
}

Copyright (C) 2015 Elif Erol, Ercan Mertoğlu. This is an open access article distributed under the Eurasian Academy of Sciences License, which permits unrestricted use, distribution, and reproduction in any medium, provided the original work is properly cited.

\begin{abstract}
This research was carried out in order to examine the effect of background music on the multiple intelligence fields of 60 children who were aged 6 and attending to a pre-school education institution in Istanbul in the 2009 - 2010 academic year. The research is an example of the experimental design. The working group of the study was made up of a total of 60 children who were aged 6 and selected from 4 different nursery classes of elementary schools in Istanbul. 30 children from two nursery classes constitute the experimental group and 30 children from two nursery classes constitute the control group. In the research, the experimental group listened to Largo musics of the Baroque era as the background music for an average of three hours five days a week for two months. The Mann Whitney U Test was used while comparing the experimental and control groups. According to surveys,students in experiment group, TIMI multiple intellegence scale's mucic, kinesthetic, mathematic and interpersonal intellegence, points which they took from these sub last test points have been found more significant high than pre testing points. In addition, students in experiment group, points which they took from sub test of last test points in TIMI multiple intellegence scales mathematic, music and interpersonal intellegence have been found significant level higher than students in control group who got same sub test's last points.
\end{abstract}

Keywords: Multiple Intelligence, Music, 6 year, Preschooll.

\section{Yaş Grubunda Geri Planda Dinletilen Müziğin Çoklu Zeka Alanlarına Etkisi}

ÖZET: Bu araştırma 2009-2010 eğitim öğretim yılında, İstanbul il genelinde Milli Eğitim Bakanlığı'na bağlı ilköğretim okulları bünyesinde okul öncesi eğitim kurumuna devam eden 60 adet 6 yaş çocuğuna geri planda dinletilen müziğin çoklu zeka alanlarına etkisini incelemek amacıyla yapılmıştır. Araştırma deneysel desene örnektir. Çalışma grubunu İstanbul il genelinde ilköğretim okullarına bağlı 4 farklı anasınıfından toplam 60 adet 6 yaş çocuğu oluşturmaktadır. 2 adet anasınıfından 30 çocuk deney grubunu, 2 adet anasınıfından 30 çocuk kontrol grubunu oluşturmaktadır. Araştırmada Barok dönemin Largo müzikleri deney grubuna geri plan müziği olarak 2 ay boyunca haftada 5 eğitim gününde ortalama 3 saat süreyle dinletilmiştir. Deney ve kontrol gruplarını karşılaştırırken Mann Whitney U Testi kullanılmıştır. Araştırma sonuçlarına göre, deney grubundaki öğrencilerin TIMI Çoklu Zeka Alanları Ölçeğinin müzik, kinestetik, matematik ve kişilerarası zeka alanları alt testlerinden aldıkları son test puanları ön test puanlarından anlamlı düzeyde yüksek bulunmuştur. Ayrıca deney grubundaki öğrencilerin TIMI Çoklu Zeka Alanları Ölçeğinin matematik, müzik ve 
kişilerarası zeka alanları alt testlerinden aldıkları son test puanları kontrol grubu öğrencilerinin aynı alt testlerden aldıkları son test puanlarından anlamlı düzeyde yüksek bulunmuştur.

Anahtar Kelimeler: Müzik, Çoklu Zeka, Altı yaş, Anasınıfı

\section{GíRIŞ}

Müzik hayatın pek çok alanında kullanılan ve yararlanılan bir araçtır. Geçmiş yıllardan günümüze sağlık alanında tedavide, okullarda eğitim aracı olarak, güncel hayatta hobi ya da meslek olarak karşımıza çıkar. Tarihte birçok düşünürün değinmeden geçemediği müziğin toplumsal etkisi için, Çin filozofu Konfüçyüs, bir milletin mutlu ve ahlaklı bir şekilde idare edilip edilmediğini anlamak için o memleketin müziğinin dinlenmesi gerektiğini, müziğin devlet kurma ve yıkma da etkili olduğunu belirtmiştir. Eski Yunan filozoflarından Eflatun ve Aristo gerek özgür insanın yetişmesinde eğitim alanında gerekse şehir devletinin yönetimi düzeninde müziğe düşen rolüne vurgu yapmışlardır. Sanat eğitimi ve onun önemli bir kolu olan müzik eğitimi demokratik, çağdaş ülkelerde önemli bir yere sahiptir. Dikta rejimlerde ise, müzik yaratıcılığına ve etkinliklerine yasaklar konulmuştur. Müziğin toplumsal işlevi "müzik-toplum" ilişkisi yönüyle, Cumhuriyetin kurucusu Atatürk tarafından da fark edilmiş ve Cumhuriyetin ilk yıllarında toplumda "yeni yaşam" biçiminin kabul edilmesinde "yeni müziğin benimsenmesi” ile kolaylıkla yerleşeceği düşünülmüştür. Atatürk, müziği kültürel ve toplumsal değişimde etkili bir araç olarak kullanırken Hitler ve Stalin'in, ülkelerindeki evrensel müzik yaratıcılığına ve etkinliklerini yasaklar koymuş, Humeyni ise iktidarı ele geçirmesiyle birlikte opera ve baleleri kapattırmıştır(Güler,2006;Güvenç,1993;Öz,2001).

$\mathrm{Bu}$ makalede de bir kısmına değinilen, dünyada yapılan pek çok araştırmada müziğin iyileştirici ve eğitici rolü günümüz koşullarında yadsınamaz hale gelmiştir. Öyle ki tramvay, park, alış veriş merkezleri gibi sosyal alanlarda dinlendirici, ameliyathanelerde sakinleştirici, okullarda zeka, dikkat gibi alanları geliştirici olarak kullanımı gün geçtikçe yaygınlaşmaktadır. Müzik ve zeka alanları arasında bir ilișki olduğu bu çalışmanın da konusudur.

\section{Çoklu Zeka Teoremi}

Howard Gardner tarafından geliştirilen Çoklu Zeka Teoremi ile bireylerin farklı alanlarda getirmiş oldukları yetenekler "zeka alanları" olarak adlandırılmıştır. Ona göre zeka, çok yönlü olup, doğuştan getirilir, iyileştirilebilir, geliştirilebilir ve değiştirilebilir. Zeka tek bir faktör ile açıklanamayacak kadar farklı yetenekleri içermektedir (Gardner,1993;Kocabaş,2003;Silver,Strong,Pericini,2000).

Gardner'ın zeka alanları; Bedensel/Devinduyusal Zeka, Sözel/Dilsel Zeka, Görsel/Uzamsal Zeka, Matematiksel/Mantıksal Zeka, İçsel Zeka, Kişiler Arası Zeka, Müziksel/Ritmik Zeka ve son olarak geliştirdiği Doğa Zekası şeklindedir(Gardner1999).

\section{Bedensel/Devinduyusal Kinestetik Zeka}


Gardner, zeka ile bedenin birbirinden ayrı olarak incelenmesinin yüzyılımızın geleneği olduğunu ve bunun yanlış bir yaklaşım haline geldiğini savunmaktadır. Bedensel zeka tüm vücut ve ellerle ilgilidir, vücut hareketlerini kontrol etmeyi ve yorumlamayı, fiziksel nesneleri manipule etmeyi ve vücut ile zihin arasında bir uyum oluşturma anlamını taşır. Koordinasyon, denge, güç, esneklik, hız gibi fiziksel yetenekleri ve bu yeteneklerin birlikte işlemesini sağlayan devimsel nitelikli becerileri içerir. Aktör, atlet, dansçı, heykeltıraş, cerrah ve tamirciler kinestetik zeka yeteneklerine sahiptir(Armstrong,2000;Bal,1999; Gardner1999;Saban,2003).

\section{Sözel / Dilsel Zeka}

Gardner'ın en ayrıntılı bahsettiği zeka alanı dil zeka alanıdır. Dil zekasının kullanımı önceki bilgiyi ve anlamayı yeni bilgiye bağlamaya yardımcı olmakta ve bağlantının nasıl olacağını açıklamaktadır. Dilin kullanımının farklı biçimlerde üretilmesine ve geliştirilmesine yardımcı olur. Sözcükleri hem sözlü hem de yazılı olarak etkili biçimde kullanabilmeyi gerektirir. Şair, yazar, politikacı, sunucu, oyun kuran ve geliştiren kişiler, editörler bu grupta yer alırlar(Demirel,2000; Gardner1999;Saban,2005).

\section{Görsel / Uzamsal Zeka}

Görsel uzamsal zekanın temelini görme duyusu ve buna bağlı olarak şekiller tasarlama ve zihinde resimler yaratma yeteneği oluşturmaktadır. Resim, heykel, grafik, mimarlık, haritacılık, satranç gibi farklı derinlik ve açılardan görmeyi gerektiren becerileri içerir. $\mathrm{Bu}$ zeka türünde gelişmiş insanlar zihinlerinde resim yaratır ve çizerler. Heykeltraş, ressam, mimar, dekoratör, tasarımcı, bahçıvan, avcı, izci, rehber gibi dış dünyadan edindiği izlenimler üzerine değişik şekiller uygulayabilen kişiler bu zeka alanında yer alırlar. (Bal,1999;Demirel,2000; Gardner1999;Pedük,2007).

\section{Matematiksel / Mantıksal Zeka}

Matematik mantıksal zeka, tümdengelim ve tümevarım ile akıl yürütme, soyut problemler çözme, birbiri ile ilişkili kavramlar, düşünceler arasındaki karmaşık ilişkileri anlama yeteneğidir. Bilimsel düşünme, objektif gözlem yapma, verilerden sonuç çıkarma, yargıya varma, hipotez kurma, mantıksal durumları, örüntüleri, ilişkileri içerir. Mantıksal matematiksel zekası güçlü olan bireyler, nesneleri belli kategorilere ayırarak, olaylar arasında mantıksal ilişkiler kurarak, nesnelerin belli özelliklerini sayısallaştırarak, hesaplayarak ve olaylar arasındaki birtakım soyut ilişkiler üzerinde düşünerek öğrenirler(Armstrong,2000;Bal,1999;Gardner1993;Gardner1999;Saban,2003).

\section{İçsel Zeka}

İçsel zeka Gardner'a göre günlük hayattaki en önemli zekadır ve diğer zeka alanlarının da tümünü birden kapsamaktadır. Kişinin kendisi ile ilgili bilgisinin olması ya da yaşamı ve öğrenmesi ile ilgili sorumluluk almasına işaret eden zekadır. Öze dönük zekası güçlü olan birey, kendi coşkularının sınırlarını anlayabilen, kendi davranışlarını yönetirken bunlara 
dayanabilen, güvenebilen, kendini dinleyebilen, içgörüsü olan kişidir. Bu zeka türünde gelişmiş insanlar, başkalarının duygu ve düşüncelerini anlama, nesne ötesi konulara konsantre olma gibi konularda başarılıdırlar ve meditasyon yapmaktan hoşlanırlar. Kendi kendini gözlem bu zekanın geliştirilmesi için kullanılabilecek bir yoldur. Din adamları psikologlar, filozoflar öze donuk zekaları gelişmiş insanlardır (Bal,1999;Demirel,2000; Gardner1999).

\section{Kişiler Arası / Sosyal Zeka}

$\mathrm{Bu}$ zeka çevredeki bireylerle iletişim kurma, onları anlama, bu kişilerin ruh durumlarını ve yeteneklerini tanıma gibi davranışlara işaret eder. Bu zekası gelişmiş insanlar moral, mizaç, güdüler ve eğilimleri fark eder ve ayrıştırırlar, sözel ve sözel olmayan iletişim ve işbirliği becerilerine, çatışma yöntemini uzlaşma becerileri ile ortak fayda amacına ulaşmak için gereken güven, saygınlık, liderlik ve diğerlerini güdüleme yeteneğine sahiptirler, başkalarının duygularına, korkularına, meraklarına ve inançlarına empati gösterme, yargılamadan dinleme ve performanslarını en üst düzeye çıkarmalarında yardımcı olma isteğindedirler. Öğretmenler, danışmanlar, politikacılar, din adamları, psikiyatrisler bu zeka türünde gelişmiş insanlardır(Altuntaş,2007; Bal,1999;Gardner1999).

\section{Doğacı Zeka/ Doğa Zekası}

Doğacı zeka Gardner'ın “Zihin Çerçeveleri” adlı eserinde yedi zeka alanına yer vermesinden daha sonra ortaya çıkmıştır. Gardner tarafindan açıklanan son zekadır ve doğal çevreyi anlama, tanıma ile ilgilidir. Doğa zekası bilgiyi verimli bir biçimde yenileyerek kullanma ve doğal nesne öğelerini, yaşam araçlarını sınıflandırma ve tanıma, duygularla doğal dünya arasında ilişki kurma yeteneklerini kapsamaktadır. Bu zeka hem yapay hem de doğal çevreyi kapsar. İzci, dağcı, biyolog ve zoologlar bu zekaları gelişmiş kişilerdir. Biyolog, jeolog, meteoroloji uzmanı, botanikçi, çiçekçi, arkeolog gibi meslek gruplarında çalışan insanlar doğacı zekaya sahiptirler(Altuntaş,2007;Gardner1999;Pedük,2007;Saban,2:003) .

\section{Müziksel / Ritmik Zeka}

Müziksel ritmik zeka türü, tonal ve ritmik kavramları tanıma, kullanma, çevresel seslere, insan sesi ve müzik aletlerine karşı duyarlık, çevredeki seslerden anlam çıkarma, konuşulan kişinin ses tonundan ruhsal durumunu kestirme, arabanın motor sesinden problem olduğunu anlama gibi davranışları içerir. Yanısıra bu zeka türü ile kişinin bir müzik parçasındaki ritime, akustik düzene, melodiye, çevreden gelen seslere olan duyarlılı̆g kastedilir. Bu zeka türünde gelişmiş insanlar müzik aleti çalmaktan, beste yapıp seslendirmekten hoşlanırlar.(Bal,1999;Bumen,2002;Gardner1999;Pedük,2007).

\section{Çocuk Gelişiminde Müziğin Önemi}

Bebeklikten itibaren işitsel algı eğitimi ile başlayan müzik eğitimi çocukların konuşmasında, kavramları öğrenmesinde, vücudunu koordineli bir şekilde kullanmasında etkili olur. Müzikle ilgilen çocuk kendisiyle gurur duyar, başarılı olma duygusunu tadar, böylece kendine güveni artar. Müziğin çocuk yaşamındaki yeri ve önemi, çocuğun kendini seslerle ifade etme, özgün 
ve güzel olanı seslerle arayıp bulması ile başlar. Anlama ve anlatma gereksinimini karşılamanın yanı sıra yaşamın değişik dönemlerinde müziğin çok yönlü işlevleri, çocuğun yaşamının bir parçasını oluşturur (Dikici,2002;Mertoğlu,1993).

Müzik etkinlikleri, çocuğun kendini ifade etmesine olanak tanırken aynı zamanda duygusal olarak rahatlaması için de firsatlar yaratır. Bu etkinlikler çocuğun başka bir yolla kazanamayacağı, tatmin edici duygusal yaşantılar kazanmasına ve vücudunun tümünü kullanmasına olanak verir. Örneğin grup olarak müzik yapma çocuğa kendini disipline etme yetisi kazandırır; vurmalı çalgıları kullanmak ritmik gelişime ve kas koordinasyonuna yardımcı olur ve dinleme yoluyla alg1 ve ayrıntıları fark edebilme yeteneği gelişir(Mertoğlu,2005;Senemoğlu, 2005).

Ünlü Macar müzik eğitimcisi Kodaly bir sözünde; "Eskiden çocuğun müzik eğitimi, doğumundan dokuz ay önce başlamalı, diye düşünürdüm. Şimdi aynı düşüncede değilim. Çocukların müzik eğitimi annenin doğumundan dokuz ay önce başlamalıdır." diyerek daha iyi ve daha mutlu bir insan olmak için herkesin müzik eğitiminden geçmesi gerektiğini vurgulamıştır. Ona göre müziksiz tam kişi yoktur. İnsanların mühendis, kimyacı olabilmesi için çocukluk çağından itibaren yetiştirilmesine gerek olmadığını ancak kulağı altı yaşından önce düzenli olarak eğitilmeyen kişilerin müzik anlayışına sahip olamayacağını savunur. Çocukluk döneminden başlayan sağlıklı ve doğru yönlendirilmiş bir müzik yaşantısı, bireyleri gelecek yaşantılarında daha başarılı, mutlu ve dengeli kılar(Akkaş,1991; aktaran,Kamacıŏlu,1993;Öztürk;2001).

Tarihsel süreç içinde pek çok filozof, eğitimci ve devlet adamı müziğin eğitimsel işlevine inanarak bu işlevden etkin olarak yararlanma yoluna gitmiştir. Eflatun müziği, bir eğlence aracı değil, güzellik ve iyilik için eğitim aracı olarak kabul etmiştir. Aristo; "Duyguları tam olarak anlatma konusunda hiçbir şey ritim ve şarkı söyleme kadar güçlü değildir. Madem ki müzik o kadar güçlü bir etkidir, şu halde müzik çocukların eğitiminde mutlaka kullanılmalıdır." söylemi ile müziğin, eğitimdeki önemine dikkat çekmiştir. Alman reformcu Martin Luther; "Eğer çocuklarım olsaydı, onların yalnız dil ve tarih değil, şarkı söyleme ve müzik eğitimi de almalarını isterdim. Teolojiden sonra ilk ve en büyük şerefi, memnuniyetle müziğe veririm.” ifadeleriyle eğitim olgusunun içinde, müzik eğitiminin yerini belirlemiştir. Çek eğitimci Comenius, ailelere ve eğitimcilere çocuklara, ninni ve şarkı söylemelerini, ayrıca, çocuklarda ritim duygusunun desteklenebilmesi amacıyla ritmik parçalar seçmelerini, 5 yaşında enstürman çalmaya başlanmasını önermiştir. İsviçreli eğitimci Pestalozzi’ye göre ise herkes müzik eğitimi görmelidir. İtalyan eğitimci Montessori de, müzik eğitim ve öğretimine büyük ilgi göstermiş, günümüzde hala popülerliğini koruyan kendi adını taşıyan okullarındaki eğitim programlarında müzikal etkinliklerin öncelikli kullanımını sağlamıştır(Güler,2006;Güvenç,1993;Öz,2001;aktaran,Poyraz ve Dere,2003).

Çocukların değişik müzik çeşitleri dinlemeleri müzik kulaklarının ve estetik duyguların gelişimi açısından oldukça önemlidir. Tarihte Osmanlıda rastlanılan müzikle terapi (müzikle sağaltım) günümüzde özellikle Avusturya da ve Avrupa ülkelerinde her geçen gün şaşırtıcı sonuçlar ortaya çıkararak yaygınlaşmaktadır. Barok dönemin largo müzikleri, Mozart'ın Re Majör, K 448 iki Piyanoluk Sonatı gibi enstrümantal bazı müzikler müzikle terapide 
kullanılmakta ve gerek zeka düzeyi gerekse diğer gelişimlerin seyrini artırdığı Türkiye dahil dünyanın pek çok yerinde yapılan araştırmalarca ispatlanmıştır(Campbell,2002;Koca, 2006; Shaw,2000).

\section{YÖNTEM}

\section{Araştırmanın Modeli}

$\mathrm{Bu}$ araştırma 6 yaş grubunda geri planda dinletilen müziğin çoklu zeka alanlarına etkisini incelemek amacıyla gerçekleştirilen deneysel bir çalışmadır.

Müzik etkinliklerinin çoklu zeka alanlarına etkisini sınamak için yürütülen bu çalışmada bir deney ve bir kontrol grubu oluşturulmuştur. Her iki grupta etkinlikler araştırmacı ve sınıf öğretmenleri tarafından yürütülmüştür. Araştırmada uygulamalar başlamadan önce ve deneysel işlemlerin bitiminden sonra ön test ve son test yapılmıştır. Bu bağlamda araştırmanın deseni ön test son test kontrol gruplu deneme modelidir. Desende bağımlı değişken altı yaş çocuklarının çoklu zeka alanları gelişimleri, çocukların çoklu zeka alanları üzerine etkisi incelenen bağımsız değişken ise geri planda dinletilen müziktir.

Araştırmanın simgesel görünümü aşağıdaki gibidir.

$\begin{array}{llll}\text { G1 } & \text { O1.1 } & \text { X } & \text { O1.2 } \\ \text { G2 } & \text { O2.1 } & & \text { O2.2 }\end{array}$

Bu simgesel ifadede:

G1: Deneme grubu,

G2: Kontrol grubu,

$\mathrm{X}$ : Uygulama,

O1: Ön test,

$\mathrm{O} 2$ : Son test, anlamına gelmektedir.

\section{Çalışma Grubu}

Araştırma için 2009-2010 eğitim - öğretim yılında İstanbul ili Milli Eğitim Bakanlığı'na bağlı Çekmeköy Anaokulu'na devam eden yaşları 5yaş 6ay - 6 yaş 5 ay arasında değişen 60 çocuk seçilmiştir. Çalışma grubunda yer alan 60 çocuktan 30'u deney grubunu, 30'u ise kontrol grubunu oluşturmuştur.

Çalışma grubunun seçiminde deney ve kontrol gruplarını eşitlemek için çocukların cinsiyeti ve gelişim özellikleri öğretmen, veli görüşleri ve okul bilgi formları esas alınarak belirlenmiştir. Özel gelişim sorunları olmayan çocuklar dikkate alınmıştır. Uygulamaya 
başlamadan önce çalışma grubundaki çocukların ve ailelerinin herhangi bir müzik ya da ritim etkinliği yapmadıkları bilgisi "Kişisel Bilgi Formaları" ile belirlenmiştir.

\section{Veriler ve Toplanması}

Çalışmada deney gurubundaki öğrencilere, Barok dönemin Largo müzikleri 2 ay boyunca haftada 5 gün, ortalama 3 saat süreyle dinletilmiştir. Kontrol grubundaki çocuklar doğal süreçlerine bırakılmıştır. Deney ve kontrol grubundaki çocuklara ön test ve son test olarak TIMI Çoklu Zeka Ölçeği uygulanmıştır.

\section{Veri Toplama Araçları}

Araştırmada çocukların çoklu zekâ alanlarını belirlemek amacıyla Dr. Teele Sue (1992) tarafından geliştirilen ve Göğebakan (2003) tarafından Türk çocuklarına uyarlanan, geçerlik ve güvenirliği yapılan TIMI Teele Inventory Multiple Intelligences (Teele Çoklu Zekâ Envanteri) ve araştırmacı tarafından hazırlanan kişisel bilgi formu kullanılmıştır.

\section{TIMI (Teele Inventory Multiple Intelligences)}

Prof.Dr.Sue Teele tarafından 1992 yılında California Üniversitesi'nde geliştirilen TIMI (Teele Inventory of Multiple Intelligences) testi, anaokulundan ortaöğretime kadar olan öğrencilerin baskın zeka alanlarını incelemek için oluşturulmuştur.

TIMI (Teele Inventory of Multiple Intelligences) yedi zeka çeşidinden her birinin özelliklerini maksimum sekiz kez seçme şansı tanıyan, 56 panda resminden olluşmaktadır. Farklı etkinlikler yapmakta olan 56 panda resmi ikişerli gruplar halde toplam 28 kartta toplanmıştır. Uygulamada, araştırmacı çocuklara 28 kartın her birini ayrı ayrı göstermiş, çocuktan beğendiği resmi seçmesini istemiş ve cevap kağıdına işaretlemiştir.

\section{TIMI Testinin Geçerlilik ve Güvenirlilik Çalışmaları}

TIMI testinin geçerlik ve güvenirliği ile ilgili literatür incelendiğinde, Sue Teele tarafından Amerikan örneklemiyle yapılan geçerlik ve güvenirlik çalışması sonucu, testin çoklu zekayı ölçmede geçerli ve güvenilir bir ölçüt olduğu anlaşılmıştır. Aynı bulgu, Amerika'da yapılan başka araştırmacılarla da doğrulanmıştır. Güvenilirliği Test-Tekrar Test tekniği ile kanıtlanmış olan bu testin istatistiksel sonuçları aşağıda belirtilmiştir:

Dört hafta ara ile testin uygulandığı öğrenci sayısı ilk uygulamada 668, ikinci uygulamada 619'dur. Her zeka çeşidi için korelasyon katsayısı $\mathrm{p}<.01$ düzeyinde anlam seviyesine göre aşağıdaki gibidir:

Sözel-Dilsel Zeka .6308

Mantıksal-Matematiksel Zeka 6602

Kişilerarası-Sosyal Zeka .5471

Görsel-Uzamsal Zeka .4870

Ritmik-Müziksel Zeka .6002 
Bedensel-Kinestetik Zeka .5153

Kişisel-İçsel Zeka .5452

Testin üç hafta ara ile uygulandığı öğrenci sayısı ilk uygulamada 929, ikinci uygulamada 812 öğrencidir. Her zeka çeşidi için korelasyon katsayısı $\mathrm{p}<.01$ anlam seviyesine göre aşağıdaki gibidir:

Sözel-Dilsel Zeka .6213

Mantıksal-Matematiksel Zeka .6840

Kişileraras1-Sosyal Zeka .4961

Görsel-Uzamsal Zeka .5812

Ritmik-Müziksel Zeka .6586

Bedensel-Kinestetik Zeka .5977

Kişisel-İçsel Zeka .6153

Testin iki hafta ara ile uygulandığı öğrenci sayısı ilk uygulamada 63, ikinci uygulamada 52 öğrencidir. Her zeka çeşidi için korelasyon katsayısı $\mathrm{p}<.01$ anlam seviyesine göre aşağıdaki gibidir:

\author{
Sözel-Dilsel Zeka .6458 \\ Mantıksal-Matematiksel Zeka .8117 \\ Kişileraras1-Sosyal Zeka .4582 \\ Görsel-Uzamsal Zeka .7717 \\ Ritmik-Müziksel Zeka .8819 \\ Bedensel-Kinestetik Zeka .5881 \\ Kişisel-İçsel Zeka .6546
}

\title{
Uygulama
}

Araştırma sosyo-ekonomik düzeyleri orta ve ortanın altı olarak sınıflandırılabilecek olan çocukların devam ettiği bağımsız bir anaokulu olan MEB Çekmeköy Anaokulunda yürütülmüştür. Uygulamalara başlamadan önce Çekmeköy Anaokulu Müdürü ile görüşmeler yapılarak, uygulamalar hakkında bilgi verilmiştir. Programın uygulanabileceği bir ortam sağlayıp sağlayamayacakları, haftada beş gün yapılacak uygulamalar için çocukların düzenli olarak çalışmalara katılmalarına izin verilip verilemeyeceği ayrıntılı konuşulmuştur. Okul yönetimi ile yapılan olumlu görüşmeler sonucunda İstanbul Milli Eğitim Müdürlüğü'nden gerekli izinler alınmıştır.

Araştırmada Deney ve Kontrol grupları belirlenirken yaş, sosyo-ekonomik düzey, cinsiyet ve öğretmen değişkenleri kontrol altına alınmıştır. Deney grubunu 3 farklı sınıftan 30 ögrenci, kontrol grubunu ise başka 3 farklı sınıftan 30 öğrenci oluşturmuştur. Deney gruplarının öğretmenlerine çalışma ayrıntılı bir şekilde açıklanmış, öğretmenlerin soruları cevaplanmış ve sınıfta dinletilmek üzere Barok dönemi largo müziklerinden oluşan müzik CD'leri sınıflara verilmiştir. Test uygulamaları için okul içinde bulunan ve bu saatler arasında boş olan sınıflardan biri kullanılmıştır. 


\section{Verilerin Çözümlenmesi}

Verilerin toplanmasının ardından istatistiksel çözümlenme için SPSS (Statistical Package For Social Sciences) 16.0 paket programı kullanılmıştır.

\section{BULGULAR VE YORUM}

\section{Tablo 1.}

\section{Cinsiyet Değişkeni için Frekans ve Yüzde Değerleri}

\begin{tabular}{lcc}
\hline Cinsiyet & f & \% \\
\hline K1z & 30 & 50 \\
Erkek & 30 & 50 \\
Toplam & 60 & 100,0 \\
\hline
\end{tabular}

Tablo 1' de görüldüğü üzere çalışma grubu, 30’ u (\%50) kız; 30’u (\%50) erkek olmak üzere toplam 60 öğrenciden oluşmaktadır.

\section{Tablo 2.}

\section{Deney ve Kontrol Grubu Değişkeni için Frekans ve Yüzde Değerleri}

\begin{tabular}{lcc}
\hline & f & \% \\
\hline Deney & 30 & 50 \\
Kontrol & 30 & 50 \\
Toplam & 60 & 100,0 \\
\hline
\end{tabular}

Tablo 2' de görüldüğü üzere çalışma grubu, 30’u (\%50) deney; 30’u (\%50) kontrol grubu olmak üzere toplam 60 öğrenciden oluşmaktadır.

Araştırmanın hipotezlerinden biri kontrol grubu ve deney grubu ön test puanları arasında fark olmamasıdır. Bu hipotezi test etmek için Mann Whitney U testi uygulanmıştır. Elde edilen sonuçlar tablo 3' de verilmiştir.

\section{Tablo 3.}

Deney ve Kontrol Gruplarının Ön Testleri Arasında TIMI Çoklu Zeka Ölçeği Puanları Arasındaki Farkın Anlamlılığını Test Etmek İçin Yapılan Mann Whitney-U Testi Sonuçları 


\begin{tabular}{|c|c|c|c|c|c|c|}
\hline $\begin{array}{c}\text { Zeka } \\
\text { Alanları }\end{array}$ & Grup & $\mathbf{N}$ & $\begin{array}{c}\text { Sira } \\
\text { Ortalaması }\end{array}$ & Sira Toplam & $\mathbf{U}$ & $\mathbf{p}$ \\
\hline \multirow{2}{*}{ Dil } & Deney & 30 & 31,13 & 934,00 & \multirow{2}{*}{431} & \multirow{2}{*}{,774 } \\
\hline & Kontrol & 30 & 29,87 & 896,00 & & \\
\hline \multirow{2}{*}{ Matematik } & Deney & 30 & 30,15 & 904,50 & \multirow{2}{*}{439.5} & \multirow{2}{*}{,874 } \\
\hline & Kontrol & 30 & 30,85 & 925,50 & & \\
\hline \multirow{2}{*}{ Uzamsal } & Deney & 30 & 30,23 & 907,00 & \multirow{2}{*}{442} & \multirow{2}{*}{,903 } \\
\hline & Kontrol & 30 & 30,77 & 923,00 & & \\
\hline \multirow{2}{*}{ Müzik } & Deney & 30 & 29,12 & 873,50 & \multirow{2}{*}{408.5} & \multirow{2}{*}{, 527} \\
\hline & Kontrol & 30 & 31,88 & 956,50 & & \\
\hline \multirow{2}{*}{ Kinestetik } & Deney & 30 & 33,40 & 1002,00 & \multirow{2}{*}{363} & \multirow{2}{*}{, 191 } \\
\hline & Kontrol & 30 & 27,60 & 828,00 & & \\
\hline \multirow{3}{*}{ İçsel } & Deney & 30 & 30,40 & 912,00 & \multirow{3}{*}{447} & \multirow{3}{*}{,964 } \\
\hline & Kontrol & 30 & 30,60 & 918,00 & & \\
\hline & Deney & 30 & 29,38 & 881,50 & & \\
\hline Kişilerarası & Kontrol & 30 & 31,62 & 948,50 & 416.5 & ,609 \\
\hline
\end{tabular}

Tablo 3 'te görüldüğü gibi, deney ve kontrol gruplarının ön testleri arasında TIMI Çoklu Zeka Ölçeği puanları arasındaki farkın anlamlılığını test etmek için yapılan Mann Whitney U Testi sonuçlarına göre anlamlı bir farklılık bulunmamıştır $(\mathrm{p}<.05)$.

$\mathrm{Bu}$ sonuca göre çoklu zeka alanları bakımından kontrol ve deney gruplarının denk olduğu söylenebilir.

Araştırmanın bir başka hipotezi de kontrol grubu ve deney grubu son test puanları arasında deney grubu lehine fark olmasıdır. Bu hipotezi test etmek için Mann Whitney U testi uygulanmıştır. Elde edilen sonuçlar tablo 4' te verilmiştir.

Tablo 4.

Deney ve Kontrol Gruplarının Son Testleri Arasında TIMI Çoklu Zeka Ölçeği Puanları Arasındaki Farkın Anlamlılığını Test Etmek İçin Yapılan Mann Whitney-U Testi Sonuçları

\begin{tabular}{ccccccc}
\hline $\begin{array}{c}\text { Zeka } \\
\text { Alanları }\end{array}$ & Grup & N & $\begin{array}{c}\text { Sira } \\
\text { Ortalaması }\end{array}$ & $\begin{array}{c}\text { Sıra } \\
\text { Toplam }\end{array}$ & U & p \\
\hline \multirow{2}{*}{ Dil } & Deney & 30 & 27,20 & 816,00 & 351 &, 126 \\
& Kontrol & 30 & 33,80 & 1014,00 & & \\
\multirow{2}{*}{ Matematik } & Deney & 30 & 35,65 & 1069,50 & & \\
& Kontrol & 30 & 25,35 & 760,50 & & \\
\hline
\end{tabular}




\begin{tabular}{ccccccc}
\hline \multirow{2}{*}{ Uzamsal } & Deney & 30 & 23,48 & 704,50 & 239.5 &, 002 \\
& Kontrol & 30 & 37,52 & 1125,50 & & \\
Müzik & Deney & 30 & 36,20 & 1086,00 & &, 009 \\
& Kontrol & 30 & 24,80 & 744,00 & & \\
\multirow{4}{*}{ Kinestetik } & Deney & 30 & 29,77 & 893,00 & & \\
& Kontrol & 30 & 31,23 & 937,00 & 428 &, 739 \\
& Deney & 30 & 26,53 & 796,00 & & \\
İçsel & Kontrol & 30 & 34,47 & 1034,00 & 331 &, 066 \\
& & & & & & \\
\multirow{2}{*}{ Kişilerarası } & Deney & 30 & 34,95 & 1048,50 & & \\
& Kontrol & 30 & 26,05 & 781,50 & &
\end{tabular}

Tablo 4'te görüldüğü gibi, deney ve kontrol gruplarının son testleri arasında TIMI Çoklu Zeka Ölçeği puanları arasındaki farkın anlamlılığını test etmek için yapılan Mann Whitney U Testi sonuçlarına göre; matematik, müzik ve kişilerarası zeka alanlarında deney grubu lehine anlamlı farklılık bulunmuştur $(\mathrm{p}<.05)$. Yani grupların son testlerinde matematik, müzik ve kişilerarası zeka puanlarının ortalamaları deney grubu lehine farklılık göstermektedir. Deney grubunun matematik, müzik ve kişilerarası zeka tesitinden elde ettikleri puanların ortalamasının kontrol grubunun aynı alt testten elde ettikleri puanların ortalamasından yüksek olduğu söylenebilir.

Bu da deney grubundaki öğrencilerin matematik, müzik ve kişilerarası zeka alanı becerilerini bağımsız değişkenin etkisiyle kontrol grubuna göre daha çok kullandıkları anlamına gelebilir.

Araştırmanın bir diğer hipotezine göre deney grubunun ön test ve son test sonuçları arasında anlamlı bir fark beklenmektedir. Bu hipotezi sorgulamak için Mann Whitney U testi uygulanmıştır. Elde edilen sonuçlar tablo 5' te verilmiştir.

\section{Tablo 5.}

Deney Grubunun Ön Testleri ve Son Testleri Arasında TIMI Çoklu Zeka Ölçeği Puanları Arasındaki Farkın Anlamlılığını Test Etmek İçin Yapılan Mann Whitney-U Testi Sonuçları

\begin{tabular}{ccccccc}
\hline $\begin{array}{c}\text { Zeka } \\
\text { Alanları }\end{array}$ & Grup & $\mathbf{N}$ & $\begin{array}{c}\text { Sira } \\
\text { Ortalaması }\end{array}$ & $\begin{array}{c}\text { Sira } \\
\text { Toplam }\end{array}$ & $\mathbf{U}$ & $\mathbf{p}$ \\
\hline \multirow{2}{*}{ Dil } & Ön & 30 & 34,45 & 1033,50 & 331,5 &, 072 \\
& Son & 30 & 26,55 & 796,50 & &, 155 \\
Matematik & Ön & 30 & 27,43 & 823,00 & 358 &
\end{tabular}




\begin{tabular}{ccccccc} 
& Son & 30 & 33,57 & 1007,00 & & \\
Uzamsal & Ön & 30 & 34,62 & 1038,50 & & \\
& Son & 30 & 26,38 & 791,50 & 326.5 &, 062 \\
\multirow{4}{*}{ Müzik } & Ön & 30 & 22,62 & 678,50 & & \\
\multirow{2}{*}{ Kinestetik } & Son & 30 & 38,38 & 1151,50 & 213.5 &, 000 \\
& Ön & 30 & 35,35 & 1060,50 & & \\
İçsel & Son & 30 & 25,65 & 769,50 & 304,5 &, 028 \\
& Ön & 30 & 32,78 & 983,50 & & \\
\multirow{3}{*}{ Kişilerarası } & Son & 30 & 28,22 & 846,50 & 381,5 &, 286 \\
& Ön & 30 & 26,52 & 795,50 & & \\
& Son & 30 & 34,48 & 1034,50 & 330.5 &, 066
\end{tabular}

Tablo 5'te görüldüğü gibi, deney grubu öğrencilerin ön testleri ve son testleri arasında TIMI Çoklu Zeka Ölçeği puanları arasındaki farkın anlamlılığını test etmek için yapılan Mann Whitney U Testi sonuçlarına göre müzik zeka alanında son testler lehine, kinestetik zeka alnında ise ön testler lehine anlamlı bir farklılık bulunmuştur $(p<.05)$. Yani bu deneysel desenli çalışmada bağımsız değişkene bağlı olarak müzik zeka alanında öğrenciler daha yüksek puan almıştır.

Araştırmanın bir diğer hipotezine göre kontrol grubunun ön test ve son tes.t sonuçları arasında anlamlı bir fark beklenmemektedir. Bu hipotezi sorgulamak için Mann Whitney U testi uygulanmıştır. Elde edilen sonuçlar tablo 6' da verilmiştir.

Tablo 6.

Kontrol Grubunun Ön Testleri ve Son Testleri Arasında TIMI Ç.oklu Zeka Ölçeği Puanları Arasındaki Farkın Anlamııı̆ı̆ını Test Etmek İçin Yapılan Mann Whitney-U Testi Sonuçları

\begin{tabular}{lcccccc}
\hline $\begin{array}{c}\text { Zeka } \\
\text { Alanları }\end{array}$ & Grup & N & $\begin{array}{c}\text { Sira } \\
\text { Ortalaması }\end{array}$ & $\begin{array}{c}\text { Sira } \\
\text { Toplam }\end{array}$ & U & p \\
\hline \multirow{2}{*}{ Dil } & Ön & 30 & 30,57 & 917,00 & 448 &, 976 \\
& Son & 30 & 30,43 & 913,00 & & \\
Matematik & Ön & 30 & 32,42 & 972,50 & 392.5 &, 383 \\
& Son & 30 & 28,58 & 857,50 & & \\
Uzamsal & Ön & 30 & 26,62 & 798,50 & 333.5 &, 078 \\
& Son & 30 & 34,38 & 1031,50 & &
\end{tabular}




\begin{tabular}{lcccccc} 
Müzik & Ön & 30 & 29,70 & 891,00 & 426 &, 715 \\
\multirow{2}{*}{ Kinestetik } & Son & 30 & 31,30 & 939,00 & & \\
& Ön & 30 & 31,58 & 947,50 & &, 624 \\
\multirow{2}{*}{ İsel } & Son & 30 & 29,42 & 882,50 & & \\
\multirow{2}{*}{ Kişilerarası } & Ön & 30 & 29,53 & 886,00 & &, 663 \\
& Son & 30 & 31,47 & 944,00 & & \\
& Ön & 30 & 32,15 & 964,50 & & \\
& Son & 30 & 28,85 & 865,50 & & \\
\hline
\end{tabular}

Tablo 6'da görüldüğü gibi, kontrol grubu öğrencilerin ön testleri ve son testleri arasında TIMI Çoklu Zeka Ölçeği puanları arasındaki farkın anlamlılığını test etmek için yapılan Mann Whitney U Testi sonuçlarına göre anlamlı bir farklılık bulunmamıştır $(\mathrm{p}<.05)$. Yani kontrol grubu öğrencilerinin zeka alanları bakımından ön ve son testlerinde denk oldukları söylenebilir.

Araştırmanın bir diğer hipotezinde deney grubundaki kız ve erkek öğrencilerin ön test ve son test sonuçları arasında anlamlı bir fark olup olmadığıdır. Bu hipotezi sorgulamak için Mann Whitney U testi uygulanmıştır. Elde edilen sonuçlar tablo 7'de verilmiştir.

Tablo 7.

Deney Grubundaki Kız ve Erkek Öğrencilerin Ön Testleri Arasında TIMI Çoklu Zeka Ölçeği Puanları Arasındaki Farkın Anlamılıı̆ı̆ı Test Etmek İçin Yapılan Mann Whitney-U Testi Sonuçları

\begin{tabular}{|c|c|c|c|c|c|c|}
\hline $\begin{array}{l}\text { Zeka } \\
\text { Alanları }\end{array}$ & Grup & $\mathbf{N}$ & $\begin{array}{c}\text { Sira } \\
\text { Ortalaması }\end{array}$ & $\begin{array}{c}\text { Sira } \\
\text { Toplam }\end{array}$ & $\mathbf{U}$ & $\mathbf{p}$ \\
\hline \multirow{2}{*}{ Dil } & $\mathrm{K}_{1 Z}$ & 30 & 30,57 & 917,00 & \multirow{2}{*}{435} & \multirow{2}{*}{,820 } \\
\hline & Erkek & 30 & 30,43 & 913,00 & & \\
\hline \multirow{2}{*}{ Matematik } & $\mathrm{K} 1 \mathrm{z}$ & 30 & 32,42 & 972,50 & \multirow{2}{*}{361.5} & \multirow{2}{*}{,171 } \\
\hline & Erkek & 30 & 28,58 & 857,50 & & \\
\hline \multirow{2}{*}{ Uzamsal } & $\mathrm{K} 1 \mathrm{z}$ & 30 & 26,62 & 798,50 & \multirow{2}{*}{386} & \multirow{2}{*}{,334 } \\
\hline & Erkek & 30 & 34,38 & 1031,50 & & \\
\hline \multirow{2}{*}{ Müzik } & $\mathrm{K} 1 \mathrm{z}$ & 30 & 29,70 & 891,00 & \multirow{2}{*}{410.5} & \multirow{2}{*}{, 548} \\
\hline & Erkek & 30 & 31,30 & 939,00 & & \\
\hline \multirow{2}{*}{ Kinestetik } & $\mathrm{K} 1 \mathrm{z}$ & 30 & 31,58 & 947,50 & \multirow{2}{*}{412} & \multirow{2}{*}{,566 } \\
\hline & Erkek & 30 & 29,42 & 882,50 & & \\
\hline İçsel & $\mathrm{K} 1 \mathrm{z}$ & 30 & 29,53 & 886,00 & 427.5 &, 726 \\
\hline
\end{tabular}




\begin{tabular}{ccccccc} 
& Erkek & 30 & 31,47 & 944,00 & & \\
Kişilerarası & Kız & 30 & 32,15 & 964,50 & 382 & \multirow{2}{*}{295} \\
& Erkek & 30 & 28,85 & 865,50 & & \\
\hline
\end{tabular}

Tablo 7‘de görüldüğü gibi, deney grubu kız ve erkek öğrencilerin ön testleri arasında TIMI Çoklu Zeka Ölçeği puanları arasındaki farkın anlamlılığını test etmek için yapılan Mann Whitney U Testi sonuçlarına göre anlamlı bir farklılık bulunmamıştır $(\mathrm{p}<.05)$. Yani deney grubundaki kız ve erkek öğrencilerin çoklu zeka alanları bakımından birbirine denk olduğu söylenebilir.

Araştırmanın bir diğer hipotezinde kontrol grubundaki kız ve erkek öğrencilerin ön test ve son test sonuçları arasında anlamlı bir fark olup olmadığıdır. Bu hipotezi sorgulamak için Mann Whitney U testi uygulanmıştır. Elde edilen sonuçlar tablo 8'de verilmiştir.

Tablo 8.

Kontrol Grubundaki Kız ve Erkek Öğrencilerin Son Testleri Arasında TIMI Çoklu Zeka Ölçeği Puanları Arasındaki Farkın Anlamlıı̆̆ını Test Etmek İçin Yapılan Mann Whitney-U Testi Sonuçları

\begin{tabular}{|c|c|c|c|c|c|c|}
\hline $\begin{array}{c}\text { Zeka } \\
\text { Alanları }\end{array}$ & Grup & $\mathbf{N}$ & $\begin{array}{c}\text { Sira } \\
\text { Ortalaması }\end{array}$ & $\begin{array}{c}\text { Sira } \\
\text { Toplam }\end{array}$ & $\mathbf{U}$ & $\mathbf{P}$ \\
\hline \multirow{2}{*}{ Dil } & $\mathrm{K}_{1 \mathrm{z}}$ & 30 & 31,22 & 936,50 & \multirow{2}{*}{428.5} & \multirow{2}{*}{,743 } \\
\hline & Erkek & 30 & 29,78 & 893,50 & & \\
\hline \multirow{2}{*}{ Matematik } & $\mathrm{K} 1 \mathrm{z}$ & 30 & 27,52 & 825,50 & \multirow{2}{*}{360.5} & \multirow{2}{*}{,175 } \\
\hline & Erkek & 30 & 33,48 & 1004,50 & & \\
\hline \multirow{2}{*}{ Uzamsal } & $\mathrm{K}_{1 \mathrm{z}}$ & 30 & 32,87 & 986,00 & \multirow{2}{*}{379} & \multirow{2}{*}{,283 } \\
\hline & Erkek & 30 & 28,13 & 844,00 & & \\
\hline \multirow{2}{*}{ Müzik } & $\mathrm{K} 1 \mathrm{z}$ & 30 & 32,52 & 975,50 & \multirow{2}{*}{389.5} & \multirow{2}{*}{,358 } \\
\hline & Erkek & 30 & 28,48 & 854,50 & & \\
\hline \multirow{2}{*}{ Kinestetik } & K1z & 30 & 31,65 & 949,50 & \multirow{2}{*}{415.5} & \multirow{2}{*}{,603 } \\
\hline & Erkek & 30 & 29,35 & 880,50 & & \\
\hline \multirow{2}{*}{ İçsel } & $\mathrm{K} 1 \mathrm{z}$ & 30 & 30,28 & 908,50 & \multirow{2}{*}{443.5} & \multirow{2}{*}{,922 } \\
\hline & Erkek & 30 & 30,72 & 921,50 & & \\
\hline \multirow{2}{*}{ Kişilerarası } & $\mathrm{K}_{1 \mathrm{z}}$ & 30 & 27,00 & 810,00 & \multirow{2}{*}{345} & \multirow{2}{*}{, 112} \\
\hline & Erkek & 30 & 34,00 & 1020,00 & & \\
\hline
\end{tabular}

Tablo 8‘de görüldüğ̈̈ gibi, kontrol grubu kız ve erkek öğrencilerin ön testleri ve son testleri arasında TIMI Çoklu Zeka Ölçeği puanları arasındaki farkın anlamlılığını test etmek için yapılan Mann Whitney U Testi sonuçlarına göre anlamlı bir farklılık bulunmamıştır $(p<.05)$. Yani kontrol grubundaki kız ve öğrencilerin çoklu zeka alanları bakımından birbirine denk olduğu söylenebilir. 


\section{TARTIŞMA SONUÇLAR ÖNERILER}

\section{Tartışma}

Yapılan araştırmada okul öncesi eğitim kurumuna devam eden 6 yaş çocuklarına geri planda dinletilen müziğin çoklu zeka alanlarına etkisi incelenmiştir. Araştırmada deneysel yöntem kullanılmıştır. Çalışma grubunda 2 adet anasınıfindan 30 çocuk deney grubunu, 2 adet anasınıfindan 30 çocuk kontrol grubunu oluşturmuştur.

Araştırmada Barok dönemin Largo müzikleri tercih edilmiştir. Bunun nedeni dünyada bu müziklerle yapılıp anlamlı farklılık elde edilen pek çok araştırmanın olmasıdır. Deney grubuna geri plan müziği olarak 2 ay boyunca haftada 5 gün ortalama 3 saat süreyle dinletilmiştir.

Araştırmanın birinci amacı doğrultusunda; 2 aylık bir uygulamadan sonra kontrol ve deney grubunun son testlerine bakıldığında yapılan Mann Whitney U Testi sonuçlarına göre; matematik, müzik ve kişilerarası zeka alanlarında deney grubu lehine anlamlı farklılık bulunmuştur. Yani grupların son testlerinde matematik, müzik ve kişilerarası zeka puanlarının ortalamaları deney grubu lehine farklılık göstermektedir. Deney grubunun matematik, müzik ve kişilerarası zeka testinden elde ettikleri puanların ortalamasının kontrol grubunun aynı alt testten elde ettikleri puanların ortalamasından yüksek olduğu söylenebilir. $\mathrm{Bu}$ da deney grubundaki öğrencilerin matematik, müzik ve kişilerarası zeka alanı becerilerini bağımsız değişkenin etkisiyle kontrol grubuna göre daha çok kullandıkları anlamına gelebilir.

Araştırmanın bu ilk amacına göre; 2 ay süre ile Barok dönemin largo ritmindeki müzikleri rutin etkinlikleri sırasında geri planda dinleyen öğrencilerin müzik, kişilerarası ve matematik zeka puanları, kontrol grubu öğrencilerinden yüksek bulunmuştur. Bu da müzik dinletiminin söz konusu zeka alanlarını geliştirdiğini düşündürebilir.

Araştırmanın ikinci amacı doğrultusunda 2 aylık bir uygulamadan sonra deney grubunun ön test ve son testlerine bakıldığında, yapılan Mann Whitney U Testi sonuçlarına göre müzik zeka alanında son testler lehine, kinestetik zeka alnında ise ön testler lehine anlamlı bir farklılık bulunmuştur. Kişilerarası ve müzikal zeka da anlamlı farklılığa çok yakın değerler almışlardır. Yani bu deneysel desenli çalışmada bağımsız değişkene bağlı olarak müzik zeka alanında öğrenciler daha yüksek puan almıştır. Bu sonuca göre; müzik dinletmenin müzik zeka alanını geliştirdiği ve kinestetik yani harekete dayalı zeka alanında ise bir düşüşe sebep olduğu söylenebilir. Bu düşüşün nedeni TIMI zeka alanları ölçeğinin seçmeli resimlere dayalı bir ölçek olması dolayısıyla bir alanın yükselmesine bağlı olarak diğer alanlarda da düşme olması gerektiği ile de açıklanabilirken müzik dinletmenin çocukların hareketlerinde bir azalmaya sebep olduğu da söylenebilir.

Müzik ile bilişsel aktivitelerin gelişimi konusunda yıllardır çeşitli araştırmalar yapılmıştır. Ancak medya tarafından en çok ilgi gören araştırma 1993'te "Mozart 
Etkisi"olarak duyurulmuş ve çok dikkat çekmiştir. Araştırma Frances Rauscher tarafından yürütülmüsstür. Amerika'da Psikoloji bölümünde okuyan 38 öğrenciye 10 dakika süre ile Mozart'ın iki piyano için yazdığı Re Maj. Piyano Sonatı (K.V.448) dinlettirilmiştir. Daha sonra öğrencilere üç boyutlu düşünme testi uygulanmıştır. Sonuçta, kontrol grubuna kıyasla Mozart dinleyen gruptan 8-9 puan daha yüksek sonuçlar elde edilmiştir. Müzik ile üç boyutlu düşünme arasındaki ilişki o dönemde ortaya atılmıştır. Sonuçlar açıklandıktan sonra araştırmacılardan birisi olan teorik fizikçi Gordon Shaw, Mozart müziğinin beyne jimnastik yaptırdığını öne sürmüştür ve şöyle demiştir: "Karmaşık yapılı müziğin matematik ve satranç gibi ileri düzey beyin etkinlikleri ile ilgisi olan belli karmaşı sinirsel örgütler arasındaki iletişimi kolaylaştırdığına inanıyoruz. Bunun aksine basit ve tekrara dayanan müziğin karşıt bir etki yapabileceğini düşünüyoruz." (Shaw,2000;aktaran,Campbell,2002;Koca,2006).

ABD'de California Üniversitesinde yapılan araştırmalar 3 ile 5 yaş arası piyano dersi alan çocuklarda fen ve matematik derslerinde başarı getirecek olan mekân zaman muhakemesinin geliştiği ortaya çıkarmıştır. Klasik müziğin etkilerini yoğun olarak araştıran ve olumlu yönlerini aktif olarak kullanan ABD eyalet bazında çeşitli kanunlarla müziği sosyal hayata sokarak ondan faydalanmaktadır; örneğin Florida'da tüm devlet okullarında arka planda klasik müzik çalınması istenmektedir. Hong Kong Üniversitesinde yapılan bir araştırmada ise 12 yaşından önce en az 6 yıl müzik eğitimi almış çocuklarla hiç müzik eğitimi almamış çocuklar arasında yaptıkları karşılaştırma ile müzik eğitimi alanların kelime dağarcığının diğerlerinden çok daha fazla gelişmiş olduğunu saptanmıştır. Giderek çoğalan araştırma sonuçları, Mozart dinlemenin zihinsel performansı arttırdığı varsayımını geçerli kılmıştır. Barok müziğin kalıpları ile beyin dalgalarındaki ritimin benzerliği keşfedildikten sonra Irvine, California Üniversitesi nöro-biyologlarından Gordon Shaw ve Frances Rauscher 1995'te 75 kolej öğrencisi ile çalışarak, ayrı ayrı grupları farklı ses ortamlarında, sessiz, Mozart'ın bir piyano sonatıyla, minimalist müzikle ve repetitive müzikle test etmişlerdir. Sonuçlar Mozart dinleyen grubun şaşırtıcı gelişme gösterdiğini ortaya koymuştur. Diğer psikolog ve nörobiyologların deney grupları olarak aldıkları çocuklar, saralılar, alzheimer hastaları, hatta farelerle yaptıkları araştırmalar ise Mozart'ın müziğinin beynin motor koordinasyonunu, görsel algısını ve düşünce sürecini hızlandırdığını ortaya koymuştur(Campbell 2002; Haines ve Gerber,1996;Koca,2006;Shaw,2000;).

Longoria, M. S. (2005) tarafından yapılan bir araştırmada, erken çocukluk döneminde müzik eğitimi programının çocukların akademik başarıları üstüne, okul öncesi öğretmenlerin düşüncelerinin etkileri incelenmiştir. Sınıfta müzik programı uygulayarak çocukların öğrenmelerini sağlayan öğretmenlerin tümü çocukların öğrenmelerine müziğin etkisi olduğunu ve müziğin oldukça etkili olan eğitim aleti olduğunu görmüşlerdir. Çocuklarda müziksel çevre varsa onların öğrenmelerini etkilediği ortaya çıkmıştır. Araştırmacı, araştırmanın sonuçlarına dayanarak müziğin çocukların öğrenme kapasitelerini sağlayabilmek için en iyi öğrenme aleti olarak kullanılmasını, sınıfta daha etkili bir şekilde müziği kullanabilmek için üniversitedeki öğretmen yetiştirme programlarının daha geliştirilmesi gerektiğini söylemiştir (Akt: Choi, 2007).

Araştırmanın üçüncü amacı doğrultusunda; 2 aylık bir uygulamadan sonra kontrol grubunun ön test ve son testlerine bakıldığında; yapılan Mann Whitney U Testi sonuçlarına göre 
anlamlı bir farklılık bulunmamıştır. Bu sonuca göre; kontrol grubunun ön test ve son testleri arasında anlamlı bir fark olmaması, araştırmada kontrol altına alınamayan değişkenlerin (2 aylık araştırma süresi boyunca okul öncesi eğitim müfredatına bağlı olarak da araştırma sonucunda yüksek çıkan zeka alanlarının geliştirilebilme ihtimali vs.), araştırmanın akışını değiştirmediği, şayet kontrol altına alınamayan değişkenler var ise de ihmal edilebilir oranlarda kaldığı düşünülebilir. Ayrıca, kontrol grubunun ön ve son testleri arası farklılığın anlamlı olmaması araştırmanın ilk iki amacında sınanan ve sonuçlanan durumların doğruluğunu ispatlar niteliktedir.

Araştırmanın üçüncü amacı doğrultusunda; 2 aylık bir uygulamadan sonra araştırmada cinsiyetlerarası ön test ve son test sonuçlarına bakıldığında; yapılan Mann Whitney U Testi sonuçlarına göre anlamlı bir farklılık bulunmamıştır.

\section{Sonuçlar}

$\mathrm{Bu}$ bölümde, müziğin çocukların çoklu zeka alanlarına etkisini inceleme:k amacıyla yapılan deneysel araştırma sonucunda elde edilen sonuçlar sunulmuştur.

\section{Geri planda müzik dinletimi yapılan deney grubunda TIMI Çoklu Zeka Alanları Ölçeği ön test - son test uygulanarak elde edilen sonuçlar aşağıda belirtilmiştir.}

İstatistiksel analiz sonuçlarına bakıldığında deney grubundaki öğrencilerin TIMI Çoklu Zeka Alanları Ölçeğinin müzik zeka alanı alt testinden aldıkları son test puanları ön test puanlarından anlamlı düzeyde yüksek bulunmuştur.

İstatistiksel analiz sonuçlarına bakıldığında deney grubundaki öğrencilerin TIMI Çoklu Zeka Alanları Ölçeğinin kinestetik zeka alanı alt testinden aldıkları ön test puanları son test puanlarından anlamlı düzeyde yüksek bulunmuştur.

İstatistiksel analiz sonuçlarına bakıldığında deney grubundaki öğrencilerin TIMI Çoklu Zeka Alanları Ölçeğinin kişilerarası ve matematik zeka alanları alt testinden aldıkları son test puanları ön test puanlarından anlamlı düzeye yakın düzeyde yüksek bulunmuştur.

İstatistiksel analiz sonuçlarına bakıldığında deney grubundaki öğrencilerin TIMI Çoklu Zeka Alanları Ölçeğinin dil, uzamsal, içsel zeka alanları alt testinden aldıkları son test puanları ile ön test puanların arasında anlamlı düzeyde bir farklılık bulunmamıştır.

\section{Geri planda müzik dinletimi yapılmayan kontrol grubunda TIMI Çoklu Zeka Alanları Ölçeği ön test - son test uygulanarak elde edilen sonuçlar aşağıda belirtilmiştir.}

İstatistiksel analiz sonuçlarına bakıldığında deney grubundaki öğrencilerin TIMI Çoklu Zeka Alanları Ölçeğinin dil, matematik, uzamsal, müzik, kinestetik, içsel ve kişilerarası zeka 
alanları alt testlerinden aldıkları son test puanları ile ön test puanların arasında anlamlı düzeyde bir farklılık bulunmamıştır.

\section{Geri planda müzik dinletimi yapılan deney grubunun TIMI Çoklu Zeka Alanları Ölçeği puanları ile kontrol grubu puanlarının karşılaştırılmasından elde edilen sonuçlar aşağıda belirtilmiştir.}

İstatistiksel analiz sonuçlarına bakıldığında deney ve kontrol grubundaki öğrencilerin TIMI Çoklu Zeka Alanları Ölçeğinin dil, matematik, uzamsal, müzik, kinestetik, içsel ve kişilerarası zeka alanları alt testlerinden aldıkları ön test puanları arasında anlamlı düzeyde bir farklılık bulunmamıştır.

İstatistiksel analiz sonuçlarına bakıldığında deney grubundaki öğrencilerin TIMI Çoklu Zeka Alanları Ölçeğinin matematik, müzik ve kişilerarası zeka alanları alt testlerinden aldıkları son test puanları kontrol grubu öğrencilerinin aynı alt testlerden aldıkları son test puanlarından anlamlı düzeyde yüksek bulunmuştur. Kontrol grubu öğrencilerinin uzamsal zeka alanı alt test puanı deney grubu öğrencilerinden anlamlı düzeyde yüksek bulunmuştur. Deney ve kontrol grubu öğrencilerinin dil, kinestetik ve içsel zeka alanları alt test puanlarının son testleri arasında anlamlı düzeyde bir farklılık bulunmamıştır.

Araştırmada kız ve erkek öğrencilerin deney ve kontrol gruplarında ön ve son test puanlarının karşılaştırılmasından elde edilen sonuçlar aşağıda belirtilmiştir.

İstatistiksel analiz sonuçlarına bakıldığında erkek ve kız öğrencilerin deney ve kontrol gruplarında TIMI Çoklu Zeka Alanları Ölçeğinin dil, matematik, uzamsal, müzik, kinestetik, içsel ve kişilerarası zeka alanları alt testlerinden aldıkları ön test ve son test puanları arasında anlamlı bir fark bulunamamıştır.

\section{Öneriler}

Yapılan deneysel çalışma sonucunda elde edilen bulgular ışı̆̆ında müzik yoluyla çocukların gelişimlerini desteklemek için aşağıdaki öneriler yapılabilir;

Okul öncesi eğitim kurumlarında müzik etkinliklerinden şarkı söyleme, dinleme çalışmalarına ağırlıklı olarak yer verildiği görülmektedir. Şarkı söyleme çalışmalarının ise diğer bir etkinliğe ya da yemek salonuna giderken çocukların sıra halindeyken yaptığı bir etkinlik halini aldığı gözlenmektedir. Bu bağlamda müzik eğitimi okul öncesi eğitim programında daha etkili kullanılmalıdır.

Okul öncesi eğitim programlarında müzik eğitimi, müzikle dans, şarkı söyleme, enstrüman çalma, yaratıcı dans ve ritim gibi her gün değişik bir etkinlikle yapılandırılmalıdır. 
Okul öncesi eğitim kurumlarındaki müzik etkinliklerinin kalitesini artırmak için maliyetin yükselmesine bakılmaksızın, ya dışarıdan uzman müzik öğretmeninin kurumda belli saatlerde ders vermesi ya da kurum öğretmenlerinin yetkin düzeyde müzik bilgisine sahip olması gerekmektedir. $\mathrm{Bu}$ hedeften yola çıkıp, dışarıdan gelen müzik konusunda uzman kişilerin çocuk gelişimi konusunda, okul öncesi sınıf öğretmenlerinin ise müzik konusunda çoğu zaman yeterli olmadıkları düşünülürse ortaya kaotik bir durumun çıkmaktadır. Bu ve benzer sorunların üstesinden gelebilmek, müzik etkinlilerinin kalitesinin ve etkililiğinin artırılabilmesi için, her bir okul öncesi öğretmen adayının, en az bir enstrüman çalarak ve nota okuyarak fakülteden mezun edilmesi sağlanmalıdır.

Okul öncesi kurum çalışanları ve ailelere müziğin çocuk gelişimine katkıları ile ilgili eğitimler verilmeli, konuya farkındalık ve ilgi sağlanmalıdır.

Eğitim kurumlarında etkinlikler arası ve serbest zaman etkinlikleri sırasındla da kulağı rahatsız etmeyecek, odaklanmayı etkilemeyecek şekilde müzik dinletimi yapılmalıdır.

Çocukların ağırlıklı olarak bulunduğu park, bahçelerde de müzik dinletimi yapılarak hem çocukların gelişimleri desteklenmeli hem de toplumun konuya ilgisi ve bilgisinin artırılması sağlanmalıdır.

Çocuklar enstrüman çalmaya özendirilmelidir. Bu bağlamda enstrüman eğitim ücretlerinin ailelere caydırıcı etkisi olmaması için belediyelerle işbirliği yapılmalıdır.

Ritim etkinlikleri, ritim aletleri okul öncesi eğitim kurumlarında daha etkin yer almalıdır.

Araştırma sonucunda müzik dinletimi yapılan deney grubu çocuklarının kinestetik zeka alanı ön test sonuçları son test sonuçlarından daha yüksek çıkmıştır, yani müzik dinleyen çocukların hareketlerinde azalma olmuştur. Bu bağlamda, benzer çalışmanın hiperaktif tanısı almış çocuklarla da yapılması önerilir. 


\section{REFERENCES}

- Akkaş, S.(1991). Okul Öncesi Eğitimde Müzik. Ankara.

- Altuntaş,N.(2007). Çoklu zeka kuramı ile öğrenmenin 7. sınıf öğrencilerinin matematik başarılarına etkisi. Yayınlanmamış yüksek lisans tezi. Marmara Üniversitesi Eğitim Bilimleri Enstitüsü.

- Armstrong, T.(2000). Multiple İntelligences in the Classroom. (2nd Ed.). Alexandria, VA: Association for Supervision and Development.

- Bal, H.( 1999). Çoklu Zeka ve Çocuklar. İzmir HİE/ Eğitim Teknoloji Formatörleri Kursu 07-18 Haziran1999.

- Bumen, N. T.(2002). Okulda Çoklu Zeka Kuramı. Ankara:Pegem A Yayıncılık.

- Campbell,D.(2002).Mozart Etkisi.(Çev: F. Çubukçu). İstanbul:Kuraldışı Yayınevi.

- Choi,J( 2007). 5-6 yaş çocuklarına yönelik hazırlanan ritim eğitimi programının çocukta ritim duyusunun gelişimine etkisinin incelenmesi. Yayınlanmamış yüksek lisans tezi. Marmara Üniversitesi Eğitim Bilimleri Enstitüsü.

- Demirel, O.(2000). Kuramdan Uygulamaya Eğitimde Program Geliştirme. Ankara:Pegem A Yayıncilık.

- Dikici, A.(2002). Orff teknğii ile verilen müzik eğitiminin matematik yeteneğine etkisinin incelenmesi.Yayınlanmamış Doktora Tezi. Ankara Üniversitesi.

- Gardner, H.(1993). Multiple İntelligences a Theory in Practice. Chicago:Published By Basic oks, A. Division Of Herper Collins Publishers.

- Gardner, H.(1999). Intelligence Reframed: Multiple İntelligences for the 21 Century. New York:Basic Books.

- Güler,N( 2006). Okul öncesi öğretmenlerin müzik etkinliklerini gerçekleştirme durumları ve eğitim gereksinimlerinin belirlenmesi. Yayınlanmamış Yüksek Lisans Tezi. Eskişehir:Anadolu Üniversitesi Eğitim Bilimleri Enstitüsü.

- Güvenç,O.( 1993). Türk Musikisi Tarihi ve Türk Tedavi Musikisi. İstanbul:Metinler Matbaa.

- Haines, B.J., Gerber, L.(1996). Leading Young Children to Music. New Jersey.

- Kamacioğlu,F.(1993).Eğitim müziği ve Kodaly metodu, 1. Ulusal Müzik Eğitimi Sempozyumu Bildirisi. Trabzon:Karadeniz Teknik Üniversitesi.

- Koca, E.(2006).Çocuğunuzu Ne Kadar Tanıyorsunuz. İstanbul:Goa Yayınları.

- Kocabaş, A.( 2003). Erken çocukluk dönemi öğretmen adaylarının kullandıkları müziği öğrenme stratejileri ve çoklu zeka alanlarının karşılaştırılması.OMEP 511.İstanbul

- Mertoğlu, E.( 1993). Okul öncesi eğitimde müziğin gelişimi ve eğitimi. 9.Okul Öncesi Eğitim ve Yaygınlaştırılması Semineri. İstanbul: Ya-Pa yayınları, ss.250-253.

- Mertoğlu, E.(2005).Okul Öncesi Dönemde Ritim Eğitimi, Okul Öncesi Eğitiminde Güncel Konular.İstanbul:Morpa Yayınları.

- Öz,N.(2001).İnsanın Kültürel Gelişiminde Müzik Eğitiminin Önemi.Uludağ Üniversitesi Eğitim Fakültesi Dergisi, Cilt: XIV, Sayı: 1.

- Öztürk, A.(2001).Okul Öncesinde Müzik Öğretim Yöntemleri. Müzik Öğretimi.Eskişehir: Anadolu Üniversitesi. Açıköğretim Fakültesi Yayınları.

- Pedük, Ş( 2007). Altı yaş grubundaki çocuklara çoklu zeka kuramına dayalı olarak verilen matematik eğitiminin matematik yeteneğine etkisinin incelenmesi. Yayınlanmamış doktora tezi.Ankara:Ankara Üniversitesi Fen Bilimleri Enstitüsü Ev Ekonomisi Anabilim Dalı. 
- Poyraz, H.,Dere,H.( 2003). Okul Öncesi Eğitiminin İlke ve Yöntemleri.Ankara:An1 Yayıncilik.

- Saban, A.(2003). Çoklu Zeka Teorisi ve Eğitimi. Ankara:Nobel Yayın Dağıtım.

- Shaw. G.(2000). Keeping Mozart in Mind. USA: Academic Press.

- Silver,Strong,Pericini(2000).So Each May Learn.Integrateding Learning Styles and Multiple Intellegences.Alexandra:VA ASD 